\begin{tabular}{|l|l|l|l|l|}
\hline $\begin{array}{l}\text { Cuadernos de Investigación Geográfica } \\
\text { Geographical Research Letters }\end{array}$ & 2020 & N$^{\circ} 46(1)$ & pp. 285-301 & eISSN 1697-9540 \\
\hline
\end{tabular}

\title{
FLUVIAL PIRACIES IN THE NE SECTOR OF THE SIERRA DE ACONQUIJA (TAFÍ VALLEY, NW ARGENTINA)
}

\author{
J.L. PEÑA-MONNÉ ${ }^{1 *}$, M.M. SAMPIETRO-VATTUONE ${ }^{2}$ \\ ${ }^{1}$ Universidad de Zaragoza, Departamento de Geografía y Ordenación del Territorio and IUCA, \\ Pedro Cerbuna 12, 50009 Zaragoza, Spain. \\ ${ }^{2}$ CONICET and Laboratorio de Geoarqueología, Universidad Nacional de Tucumán, \\ 4000 San Miguel de Tucumán, Argentina.
}

\begin{abstract}
The Sierra de Aconquija is a recently uplifted mountain chain in NW Argentina. The NE side of the sierra is drained by the Muñoz and Los Alisos rivers - whose base level is the Las Carreras Depression that is located to the SW of the Tafi valley. Two of the major headwaters of the Muñoz River suffered during its Holocene development from piracy by the Los Alisos River. These piracies had important consequences on the size of both basins and the functioning of their alluvial fans. The main causes of the captures were changes in river dynamics during Lateglacial and Holocene glacial events. Neotectonic activation does not seem to be the most determining factor, although there are active Holocene faults nearby (Las Carreras Fault 2). Geomorphological and human occupation data recovered from the alluvial fans enables us to estimate that the most recent capture was produced during the Late Holocene.
\end{abstract}

Capturas fluviales en el sector NE de la Sierra de Aconquija (Valle de Tafí, Noroeste de Argentina)

RESUMEN. La Sierra de Aconquija es una cadena montañosa recientemente elevada localizada en el Noroeste de Argentina. El lado NE de la sierra es drenado por los ríos Muñoz y Los Alisos - cuyo nivel de base es la depresión de Las Carreras localizada al SW del valle de Tafí. Dos de las cabeceras más importantes del río Muñoz sufrieron procesos de captura durante el Holoceno llevados a cabo por el río Los Alisos. Estas capturas tuvieron importantes consecuencias en las dimensiones de ambas cuencas y en el funcionamiento de los respectivos abanicos aluviales. Se propone que las principales causas fueron los cambios en la dinámica fluvial producidos durante el Tardiglacial y los eventos glaciales holocenos. La activación neotectónica no parece ser un factor determinante, aunque hay fallas activas holocenas en las proximidades (Falla Las Carreras 2). Los datos geomorfológicos y la ausencia de ocupaciones humanas en el cono aluvial 
de Los Alisos permiten estimar que la captura más reciente ocurrió durante el Holoceno Superior.

Keywords: captures, morphosedimentary units, Lateglacial-Holocene, alluvial fans, Sierra de Aconquija.

Palabras clave: capturas, unidades morfosedimentarias, Tardiglacial-Holoceno, abanicos aluviales, Sierra de Aconquija.

Received: 31 April 2019

Accepted: 23 May 2019

*Corresponding author: J.L. Peña-Monné, Universidad de Zaragoza, Departamento de Geografía y Ordenación del Territorio and IUCA, Pedro Cerbuna 12, Zaragoza 50009 (Spain). E-mail address: jlpena@unizar.es

\section{Introduction}

Fluvial networks in young mountainous chains need time for adaptation. They begin with constant reorganizations (Lavé, 2015) due to neotectonic reactivations and fluvial piracies. Fracture networks offer the best routes to settle river courses as they cause subordination network processes until the final settlement of the watersheds (Bishop, 1995; Stokes and Mather, 2003; Calvache and Viseras, 1997). These reorganizations continue through captures between fluvial courses. Sometimes, these processes are complex and difficult to understand (Calvache and Viseras, 1997; Le Roux and Harmand, 1998; Mather, 2000; Maher et al., 2007; Stokes et al., 2002; Miskesell et al., 2010; Stamm et al., 2013).

Understanding captures can be achieved by the identification of different processes such as elbows of capture, windgaps, exceptional incisions, abandoned valleys, knickpoints with waterfalls, and changes in fluvial discharges (Zaprowski et al., 2002; Miskesell et al., 2010). Climatic changes and tectonic activity are the most common causes for capture triggering mechanisms (Stokes and Mather, 2003; Perucca et al., 2018).

NW Argentina, with the presence of recently uplifted mountainous chains, such as the Sierra de Aconquija and Cumbres Calchaquíes (Fig. 1) and other reliefs in the Calchaquíes valleys and the Sierras Pampeanas (Strecker, 1987; Strecker et al., 1989; Gutiérrez et al., 2003; Gutiérrez and Mon, 2004; Casa, 2009; Hongn et al., 2014, Perucca et al., 2018) is an adequate framework for piracy generation. Recent glaciarism also favors captures due to the aggressive fluvial dynamics related to melting. In addition, the high gradients of the range and the asymmetry among neighboring basins can also propitiate piracies. The objective of this paper is the identification, description, and mapping of the captures between the Muñoz and Los Alisos rivers in the NE of the Sierra de Aconquija and the proposal of a relative chronology and genesis for these processes. Moreover, the captures were also related with the previously established regional evolutionary model. 


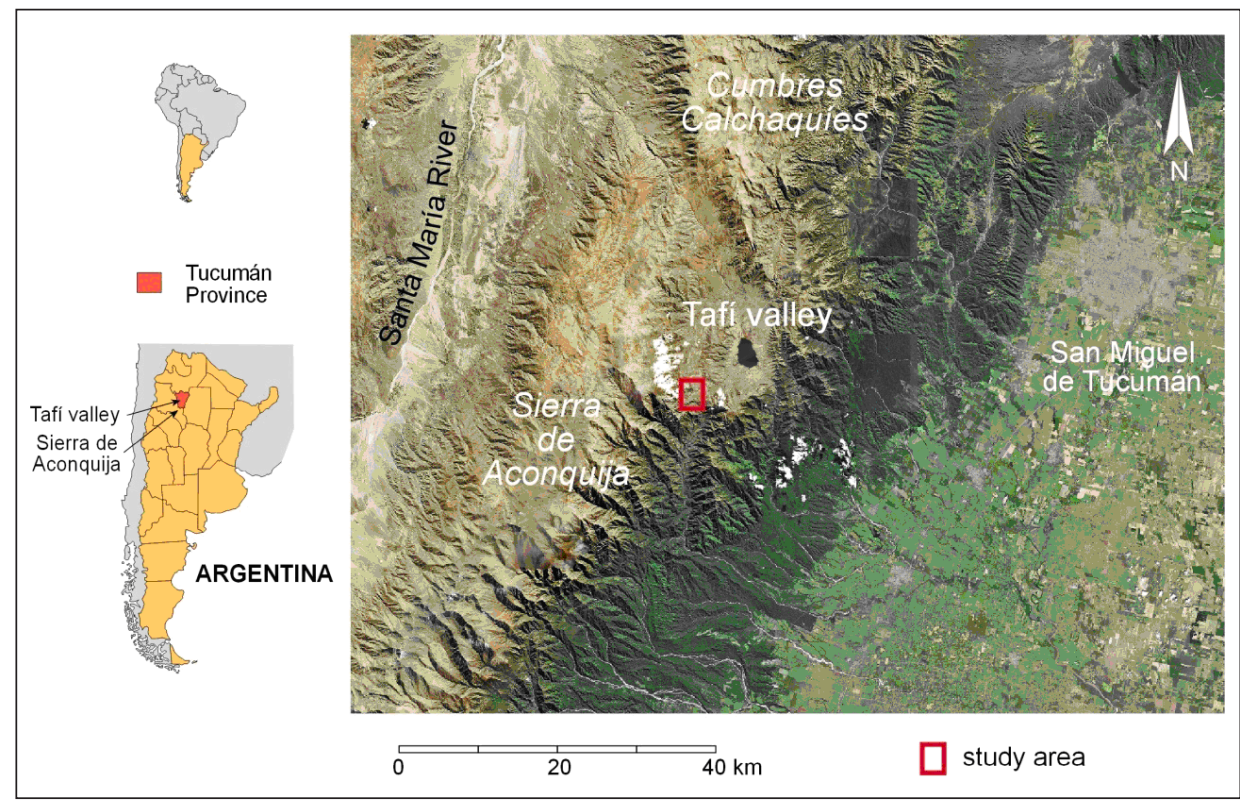

Figure 1. a) Location maps of the Tucumán province in NW Argentina; b) Study area location in the framework of the relief units of the Tafi valley and the Sierra de Aconquija sector.

\subsection{Regional settings}

The Tafí valley is a tectonic depression located in the Sierras Pampeanas of the Tucumán Province, NW Argentina (Fig. 1). It is an elongated depression, NNW-SSE oriented, following the Tafí Fault, divided in two main basins by the presence of an intermediate relief called the Loma Pelada (2680 m a.s.1.). The eastern area of the valley is crossed by the Tafí River and it is properly named the Tafí valley, while the western sector is called the Las Carreras valley. This valley is bordered to the east by the Loma Pelada and to the west by the Sierra de Aconquija (Cerro Muñoz 4600 m a.s.1.) (Figs. 2a, 2b). The Las Carreras valley has a double drainage: the Muñoz River (or Las Carreras River) flows to the north to merge with Tafí River; while the Mollar River flows to the south collecting waters from the Los Alisos River and other rivers to join the Tafí River at La Angostura reservoir. Most of the waters are from the Sierra de Aconquija as Loma Pelada has few water courses.

The surrounding mountains exert an important role as climatic barriers impeding the arrival of wet winds from the southeast. The climate is semiarid with an annual rainfall of $450-550 \mathrm{~mm}$. Most rains fall in the summer ( $82 \%$ of the total) and average annual temperature is $13.1^{\circ} \mathrm{C}$. Vegetation is adequate to the arid climate and adapted to the various soils and topographical contrasts.

Geologically, the Las Carreras valley is conditioned by the western fault of Loma Pelada, and is N-S oriented (Gutiérrez and Mon, 2004). The Sierra de Aconquija is composed of Precambrian and Lower Paleozoic granite, granodiorite, and metamorphic rocks (schists 

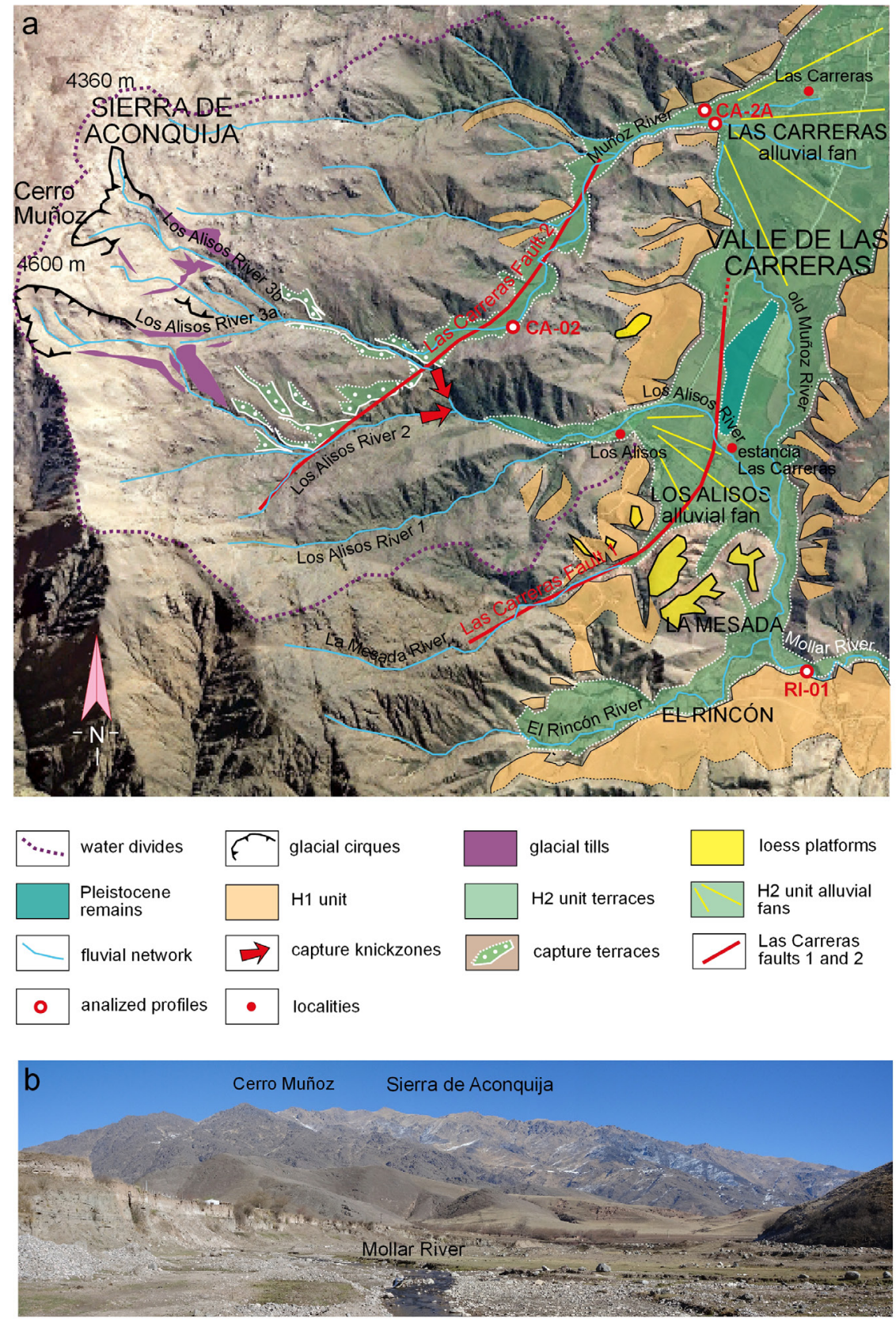

Figure 2. Geomorphological scheme made over a Google Earth image (2016), and a panoramic view of the NE side of the Sierra de Aconquija (modified from Peña-Monné and SampietroVattuone, 2019; Sampietro-Vattuone and Peña-Monné, 2019). 
and phyllites), with abundant pegmatite and quartz dykes. According to Strecker (1987), its most recent uplift was less than 1.2 Ma. Rocky substrate is found on the uncovered surface, while tors and castle kopjes are common in the highlands. The summits are flattened by a Late Cretaceous erosive surface (Sobel and Strecker, 2003), exhumed during the Neogene by the range uplift and affected by Quaternary ice caps. In the SW sector, several glacial cirques were identified together with some rock glaciers (Peña-Monné and SampietroVattuone, 2019). These cirques are the headwaters of the El Rincón, La Mesada, Los Alisos, and Muñoz rivers (Fig. 2a). Quaternary deposits are dominant in the bottom of the depression, and examples include the loess platform in the La Mesada (Fig. 2a) (Kemp et al., 2003; Schellenberger et al., 2003), several isolated Pleistocene detritic hills (Fig. 2a), and large accumulations of Holocene slope, terraces, and alluvial fans.

\subsection{The Lateglacial-Holocene evolutionary model}

To understand the reorganization of the fluvial network in the context of the valley's geomorphology it is necessary to discuss the main features of the evolutionary model developed by Sampietro-Vattuone and Peña-Monné (2016) and Peña Monné and Sampietro Vattuone $(2016,2018)$ accompanied by some figures of the study area. Four aggradational stages (H1 to H4 units) were identified in the Tafí valley that were separated by incision phases (Fig. 3a). The H1 unit is composed of slopes, fluvial terraces, and alluvial fans dating from the Lateglacial to the Middle Holocene ( $c a .13 \mathrm{ky} \mathrm{cal} \mathrm{BP}$ to $4.2 \mathrm{ky}$ cal $\mathrm{BP}$ ). The morphosedimentary records of this stage are important in the valleys of the Mollar and Muñoz rivers. Figure 3a shows that the lower section of the profiles (H1A) ends at $c a .10 \mathrm{ky} \mathrm{cal} \mathrm{BP}$ and at the same time as the sedimentation of a tephra layer named V0 - as interpreted by Sampietro-Vattuone and Peña-Monné (2016) and Sampietro-Vattuone et al. $(2017,2019)$. This layer is also visible in the profiles of Figures $3 \mathrm{~b}$ and $3 \mathrm{~d}$. Before the V0 ashfall, the $\mathrm{H} 1 \mathrm{~A}$ section shows a rhythmic sequence of peats and sands of considerable paleoenvironmental relevance, chronologically defined by several radiocarbon datings (Fig. 3a). The section was interpreted by Peña-Monné and Sampietro-Vattuone (2019) as the result of glacial melting processes produced during the Younger Dryas in the headwaters of Aconquija (stage G1). The H1B subunit was drier than the previous period and covers the period between $c a .10 \mathrm{ky} \mathrm{cal} \mathrm{and} 4.2 \mathrm{ky} \mathrm{cal} \mathrm{BP}$. The end is marked by the starting of an incision phase and a new ashfall in the event called V1 (Figs. 3a-3e) that occurred around $4.2 \mathrm{ky}$ cal BP (Sampietro Vattuone et al., 2017,2019). During this period, another cold phase was identified enabling the formation of new glaciers (Neoglaciation) (stage G2; Peña-Monné and Sampietro-Vattuone, 2019). In Figure 3a, the $\mathrm{H} 1$ unit is mainly represented by slope deposits because this stage was later covered in the bottom areas and alluvial fans by the $\mathrm{H} 2$ unit. Accordingly, the $\mathrm{H} 1$ deposits are only visible in the lower sections of incisions, as shown in the profiles and photographs in Figure 3. As a result of these processes, the $\mathrm{H} 2$ unit reaches its largest extension in the valleys (Fig. 2a) and is also present in several stratigraphic profiles (Figs. 3e, 3f). It dates to after $4.2 \mathrm{ky}$ cal BP and reaches at least until $14^{\text {th }}$ century during the Upper Holocene (Fig. 3a). A new ashfall (V2) was recorded interbedded between H2 and $\mathrm{H} 3$ units (Figs. 3a, 3e, 3f). The final unit is H4. These last two units (H3 and H4) are less important and are geomorphologically represented by fluvial terraces. 
a

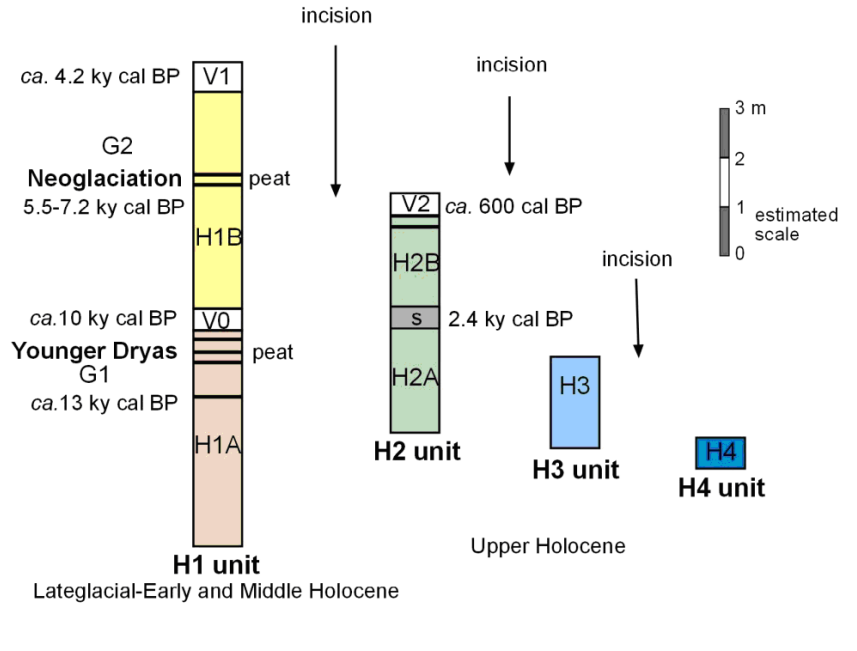

b
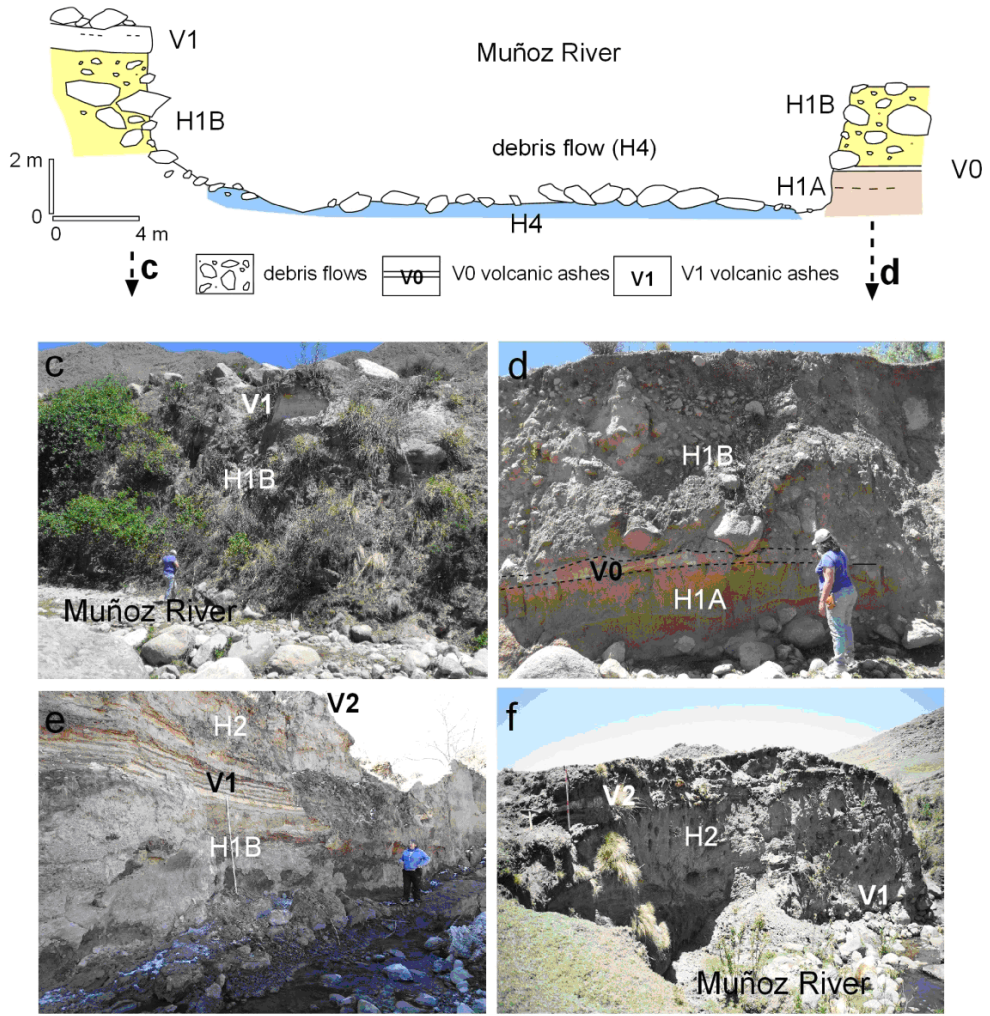

Figure 3. a) Synthetic scheme of the four morphosedimentary units from the Tafi valley; $b$ ) cross-section of the Muñoz River at the apex of the Las Carreras alluvial fan-see the main sedimentary units; and $(c, d)$ detailed photographs; $e)$ units in a profile of the El Rincon area; $f$ ) profile of the upper course of the Muñoz River. 


\section{Methodology}

A geomorphological map was made using Google Earth images (2016) to understand the spatial distribution of the geomorphological components and their spatial and temporal connectivity (Sampietro-Vattuone and Peña-Monné, 2019). This cartography was complemented with fieldwork during 2017-2018 that used DJI Phantom 4 and Phantom 4 Pro drones to photograph inaccessible sites and obtain images with the most useful perspectives. Field data positions were recorded with a GPS Garmin Montana 650. Numerous profiles were recorded, but the profile of the Las Carreras alluvial fan (CA2A) and another two profiles from the Las Carreras fault 2 (CA-10) were selected for this paper. The location of these profiles can be seeing in Figure 1. Radiocarbon datings were made in the Laboratorio de Radiocarbono (Universidad de La Plata-Argentina) and DirectAMS Laboratory (USA) and these were published in previous papers (Peña-Monné and Sampietro-Vattuone, 2019). Datings were calibrated with OxCal v. 4.2 software, using the Southern Hemisphere calibration curve. Results were expressed in years cal BP with two sigma. Volcanic ashes were identified and analyzed in the INENCO laboratory (CONICET-UNSA) to understand their geochemical characteristics and measure their chronologies (Sampietro Vattuone et al., 2017).

\section{Results}

The rivers of the NE side of Sierra de Aconquija are composed of a dense network of tributaries. In most cases, they are adapted to fractures in the substrate network. The two main rivers, the Los Alisos and Muñoz rivers, drain to the NE of the range and its piedmont. As a consequence of the recent uplift, these rivers have steep gradients between the summits $(4600 \mathrm{~m}$ ) and valley bottom (2020 m a.s.l. at Los Alisos and Las Carreras). These fluvial courses suffered several readjustments in their drainage organization. During a large part of the Pleistocene and Holocene evolution, the Los Alisos 2 and 3 catchments consisted of two of the four headwaters of the Muñoz River basin before being captured by Los Alisos 1 River (Figs. 4a, 5a). Initially, there is an important slope difference between both rivers, while Muñoz River has a gradient of $18 \%$ in the upper course, the Alisos 1 River reaches $31 \%$ (Fig. 5a). These differences among two neighboring basins create favorable conditions for a future piracy when other triggering factors appear. The Los Alisos 1 River originally had a small basin $\left(5.64 \mathrm{~km}^{2}\right)$ formed by only one fluvial segment in a straight and narrow valley with only small tributaries in its final section before entering the Las Carreras valley. Its headwater reached $3960 \mathrm{~m}$ a.s.1., much lower than the headwaters of the basins located to the west, so neither glaciers nor rock glaciers developed within and it had little flow and transport capacity. At the same time, the Muñoz River basin reached $29.66 \mathrm{~km}^{2}$ in size and contained ice masses during the Younger Dryas and Neoglacial in its headwaters. Its greater discharge capacity could explain the large extension of the Las Carreras alluvial fan $\left(5.50 \mathrm{~km}^{2}\right)$ (Figs. 2a, 4a).

The basins of Los Alisos 2 and 3 rivers oriented their drainage in an almost parallel direction from NNW to SSE, and both streams turned downstream to SW-NE following an elongated fault (Las Carreras fault 1) whose position was approximately diagonal to the Las Carreras depression (Fig. 2a). It is possible to infer the original 
trace because several sectors of the abandoned floodplain are preserved in the Los Alisos 1 and 2 rivers and form terraces. It is possible to estimate the valley width at around $370 \mathrm{~m}$ (Fig. 2a). After the confluence of the Los Alisos 2 and 3 rivers they flowed along the course of the present Muñoz River and maintained a similar width until the Las Carreras alluvial fan.

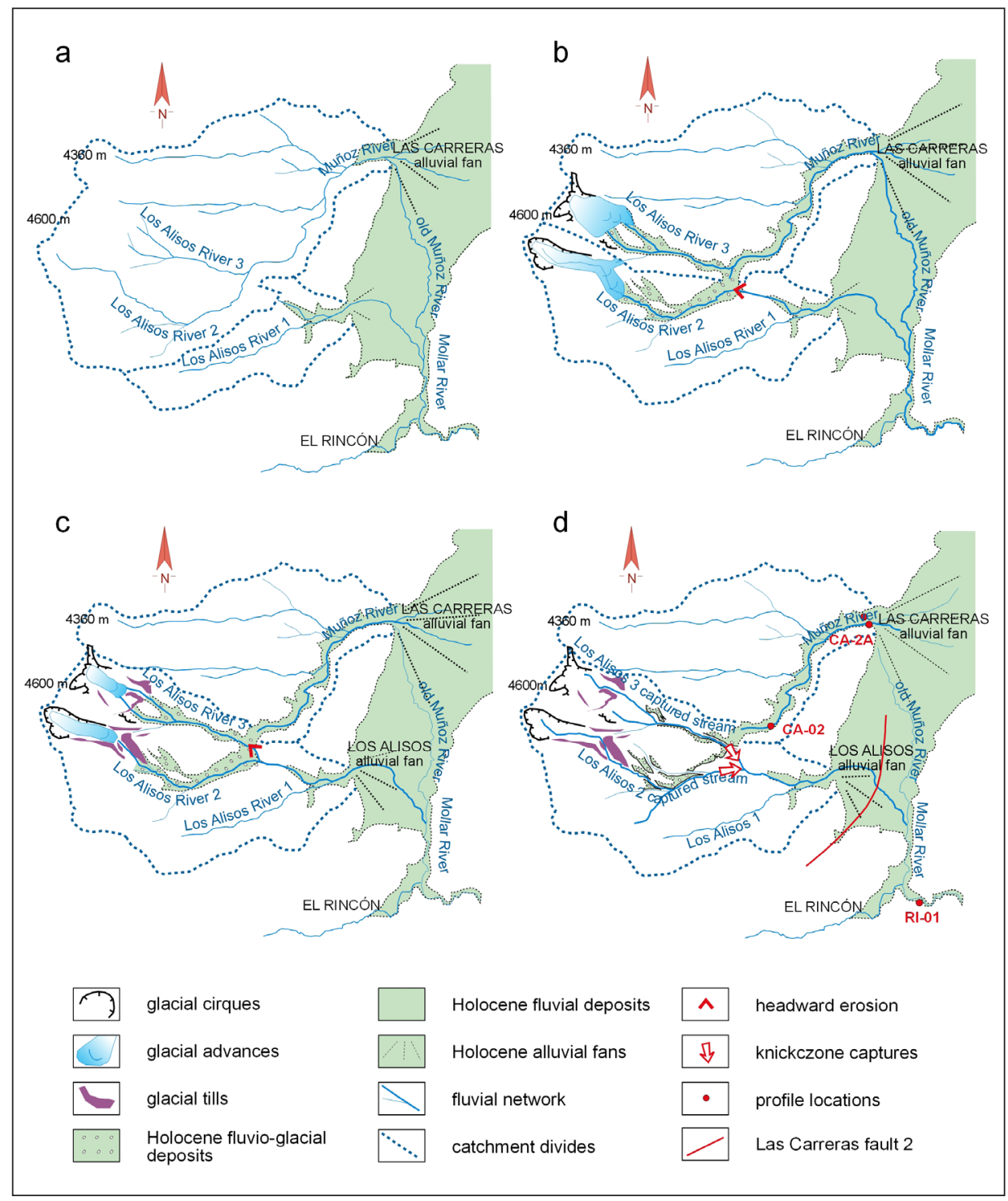

Figure 4. Evolutionary schemes showing the variation in the basin sizes and tracing the river courses: a) before the capture; b) Los Alisos River 2 capture; c) Los Alisos River 3 capture; d) present arrangement with the position of described profiles and location of Las Carreras fault 2. 


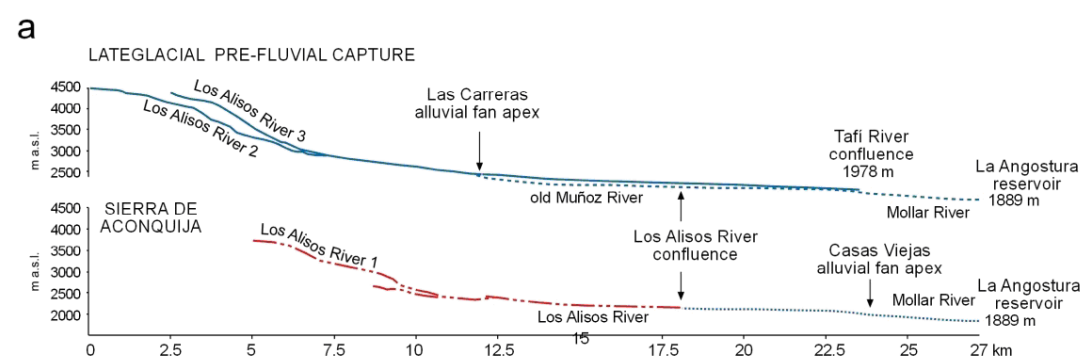

b

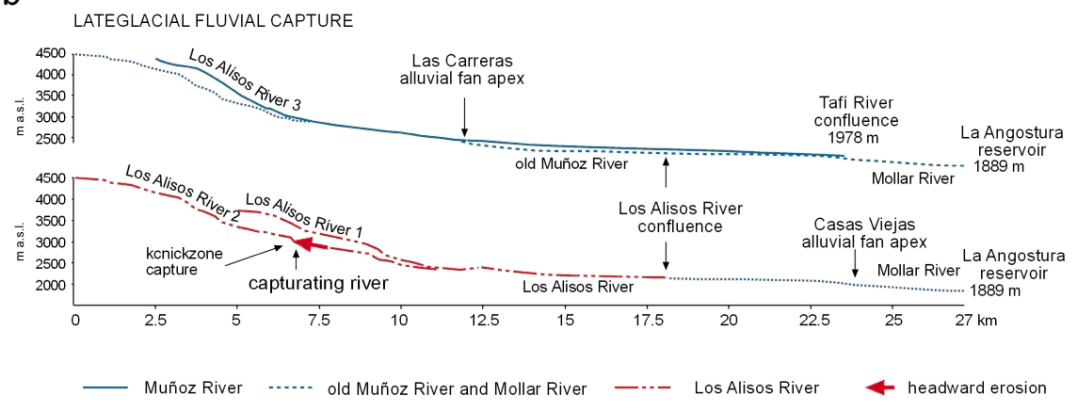

C

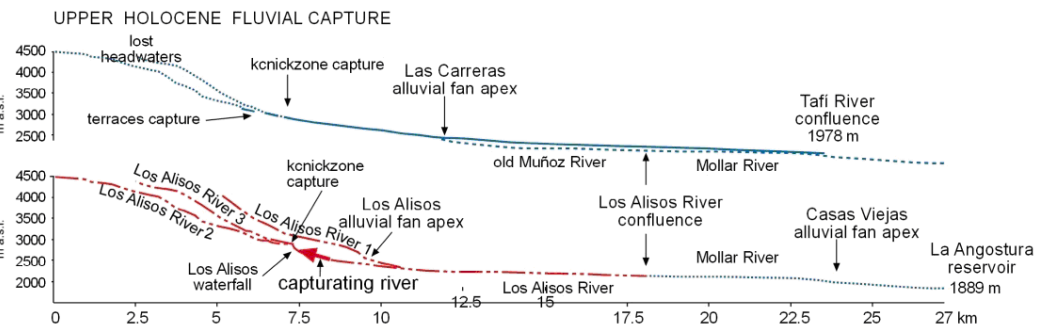

Figure 5. Variations in the longitudinal profiles of the Los Alisos and Muñoz rivers due to piracy processes: a) before the capture; b) after the capture of the Los Alisos 2 River; c) after the capture of the Los Alisos 3 River.

The first piracy was produced by a tributary of the middle course of the Los Alisos 1 River, when it reaches the Los Alisos 2 River, located $500 \mathrm{~m}$ above, by headward erosion (Figs. 4b, 5b). Later, from the already captured Los Alisos 2 River, a new headward erosion process upstream pirated the Los Alisos 3 River (Figs. 4c, 5c). The formation of a new lower base level always generates imbalances in captured systems, as pointed out by Stokes et al. (2002) due to changes in the distribution of the catchment sizes (Bishop, 1995; Mather, 1993, 2000; Zaprowski et al., 2001, 2002). In the northern valley (Los Alisos 3 River) a gorge was cut in the interfluve (water gap). This gorge currently reaches more than $300 \mathrm{~m}$ depth and leads to a large waterfall (Figs. 6a-6d) at the end of the valley. The backward erosion process is still very active and there are numerous 
recent landslides affecting the escarpments. In the Los Alisos 2 River the headwards was less intensive, with a longer incision from the knickzone that left behind some precapture terraces mainly on its north margin (Figs. 2a, 6c). The incision reached the old floodplains by deep entrenchments of the Los Alisos 2 and 3 rivers (Fig. 4d).
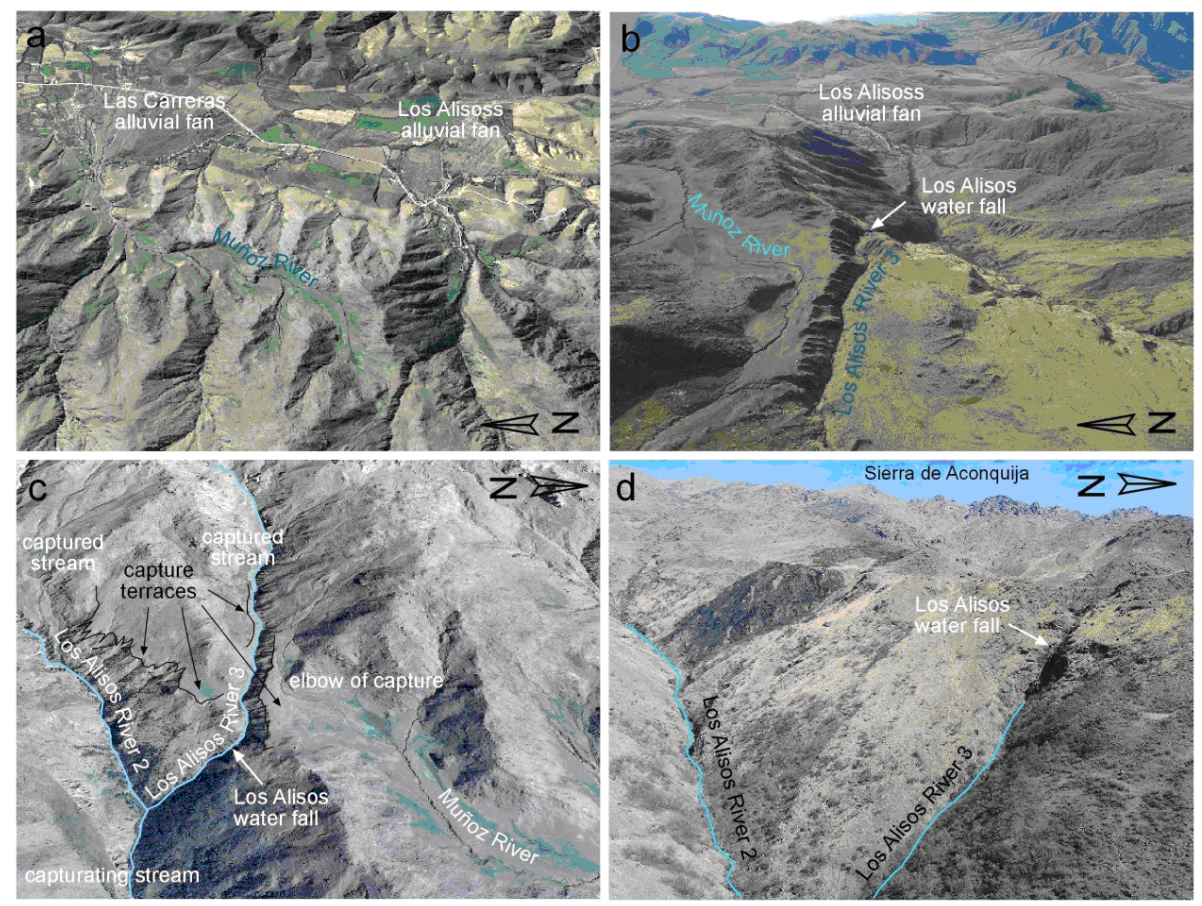

Figure 6. Images of the capture area and both large alluvial fans; a) general view from Google Earth (2016); b) oblique aerial photograph of the capture knickzone; c) detail of the Google Earth (2016) image of headward incision in the Los Alisos River capture; d) drone photograph of the waterfall sector in the capture area.

The impact of river piracy caused an increase in the size of Los Alisos River basin (Figs. 4b, 4c, 5b, 5c) of around 73\% (the basin is now $20.44 \mathrm{~km}^{2}$ in size), and stream power also predictably increased, as well as flood magnitude and frequency (Stokes et $a l ., 2002$ ). In contrast, from the elbow of capture, the Muñoz River (having lost $50 \%$ of its basin now measures $14.86 \mathrm{~km}^{2}$ ) decreased its stream power and transport capacity (Figs. 4c, 5c). There are several large geomorphological post-piracy effects - especially in the alluvial fan dynamics. In the Las Carreras alluvial fan (Fig. 2) only the central and northern courses diverging from the apex remain active because deep incisions were generated (Fig. 7a), and almost $50 \%$ of the alluvial fan remains inactive. Specifically, one of the most active channels (the old Muñoz River in Fig. 4) was disconnected from the main drainage system. At present, all the Muñoz River waters are flowing towards Tafí River in the northern sector. The abandoned channel is used only by lateral secondary 
tributaries until the confluence with the Los Alisos River. After the capture, the Los Alisos alluvial fan became more dynamic, expanded (Fig. 7b), and developed a deep apex that penetrated upstream and in which rock avalanches and debris flow processes dominated (as can be inferred from its deposits).
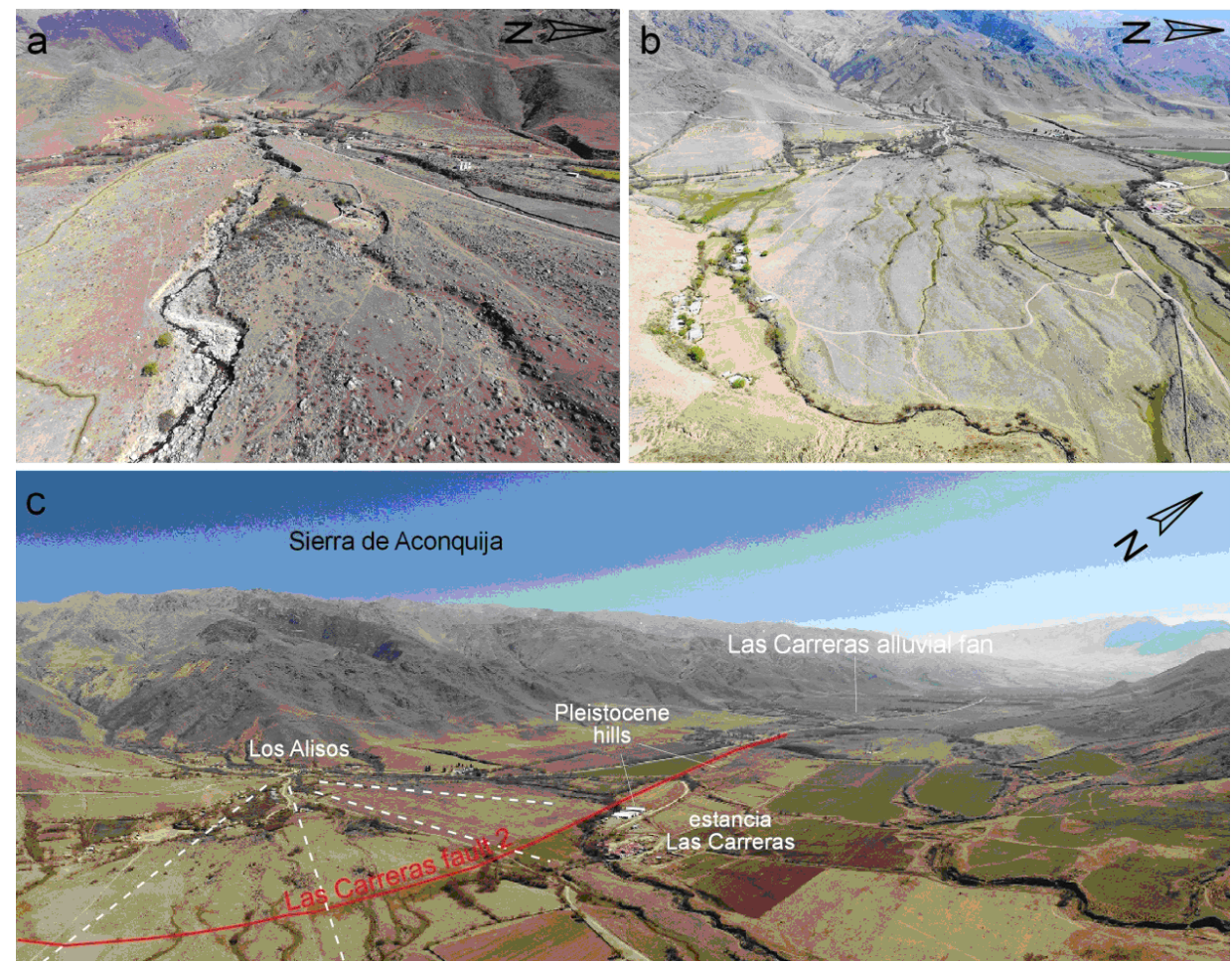

Figure 7. a) central sector of the Las Carreras alluvial fan; b) southern area of the Los Alisos alluvial fan; c) general view of the Las Carreras valley, with both alluvial fans, Las Carreras and Los Alisos, and Las Carreras Fault 2.

\section{Discussion}

One of the most important geomorphological features for understanding the piracy genesis and reconstructing the process are the accumulations that form the old general floodplain of the Muñoz River before, during, and after the captures. The incisions that gave place to the isolation of the fluvial terraces of the captured rivers (the Los Alisos 2 and 3 rivers) were produced by headward erosion by the capturing river over the old floodplains. In the Los Alisos 2 River sector the terrace seems to be composed of just the lower units of the Holocene regional sequence (H1) and consists of coarse detritic materials from the transition areas between fluvioglacial and fluvial environments. However, in the sector of the Los Alisos 3 River, the terrace also contains many Middle Holocene deposits and the incisions are therefore later than the capture of the Los Alisos 
3 River. The continuity observed on this terrace with the present Muñoz River terraces enables us to infer that they are part of the same floodplain and are built on the same basal sedimentary sequence produced before the capture took place. As the successive captures occurred, the sedimentary sequences were truncated in the captured sectors due to the incision of the deposits. Thus, the most complete profiles, composed of distal sediments and peat layers (Fig. 3f) are in the floodplain of the Muñoz River headwater. This sector also conserves the most recent tephra (V2).

The lower river courses, where the distal sections of the alluvial fans are located, also offers useful information about the evolutionary dynamics of these rivers. The Muñoz River reveals good continuity downstream as can be seen in the outcrops recorded up to the apex of the Las Carreras alluvial fan (Figs. 3b-3d), as well as in the incision of the old Muñoz River. In these accumulations it is possible to see the V0 and V1 ash layers with notable continuity, while V2 ashes are not identifiably interbedded (as in the upper section of the river). The $\mathrm{V} 2$ ashes must have been eroded by the wind as no record remains. The Las Carreras alluvial fan shows the entire Lateglacial and Early-Middle Holocene sedimentary record for the central and south sector, where granite blocks and metamorphic rocks are significantly weathered. At present, the most active area is located to the north and is affected by a deep incision, including $\mathrm{H} 3$ and $\mathrm{H} 4$ stages in its interior. At the Los Alisos alluvial fan it was impossible to find the old ashes except in the distal section, i.e. close to the Estancia Las Carreras where V1 ashes are found. The surface of Los Alisos alluvial fan is formed of large blocks and debris flow deposits of younger appearance that are less weathered than those of the Las Carreras alluvial fan (Figs. 7a, 7b).

Besides, there is human information related to Late Holocene Prehispanic settlements useful for this interpretation. The old sector of the Las Carreras alluvial fan was densely occupied by Formative agricultural people from the Tafí Culture, chronologically spanning from 2435-2059 cal BP (Gónzalez and Núñez Regueiro, 1960) and 957-811 cal BP (Roldán et al., 2016). This type of settlement over alluvial fans is very common throughout NW Argentina (Sampietro-Vattuone, 2010; Maldonado et al., 2016; Sampietro-Vattuone et al., 2018). However, the Los Alisos alluvial fan was not occupied by this Prehispanic people neither later peoples. This enables us to infer that the Muñoz River capture must have been produced after the V1 ashes (dated to $c a$. $4.2 \mathrm{ky}$ cal BP) were deposited, and at some time close to the beginning of Formative culture settlement. The Los Alisos alluvial fan, mainly as a consequence of the capture of Los Alisos 3 River, must have increased its characteristic debris flow and rock avalanche dynamic as identified in the lower section of the Los Alisos River and the main alluvial fan surface. Under such circumstances, human settlement would have been impossible. At present, most of the alluvial fan is inactive due to the river's inability to move large blocks and so its channel has moved north.

Lastly, it is necessary to assess the possibility of a neotectonic influence. The neotectonic dynamics of the Tafí valley and the Sierra de Aconquija, as well as other units of the Sierras Pampeanas, were studied by various authors (including Strecker, 1987; Fauqué and Strecker, 1987; Strecker et al., 1989; Costa et al., 2000; Gutiérrez et al., 2003; Gutiérrez and Mon, 2004; Casa, 2009; Casa et al., 2011; Hongn et al., 
2014). The importance of the tectonic deformations in the fluvial basin activation that generated capture processes was also described by Stokes and Mather (2003), Gutiérrez et al. (2003), Perucca et al. (2018), among others. An important fault (Las Carreras Fault 2) (Fig. 2a, 7c) was identified crossing the Los Alisos alluvial fan from $N$ to $S$. This fault favors the formation of a scarp that is uplifting the hills close to Estancia Las Carreras and bringing up Pleistocene substrate. The fault may be following along the same alluvial fan because of the presence of an accompanying surge line (Fig. 7c). An outcrop close to Estancia Las Carreras enables us to see Pleistocene gravels and sand levels deformed by an inverse fault heading N-S. It is also possible to identify some deformations on the V1 ashes (ca. $4.2 \mathrm{ky} \mathrm{BP}$ ). However, no direct links were established with the capturing area. Thus, we do not have enough data to support a tectonic cause.

Gathering together information from old floodplains and alluvial fans and having discarded the tectonic influence, we believe that the capture of the Los Alisos 2 and 3 Rivers is a consequence of the major altitudinal differences between the old headwaters of the Muñoz River and that of the Los Alisos River 1 and its tributaries (500 m). However, the process must have been triggered by a large increase in fluvial flows, and this is only made possible in these low rainfall environments by the presence of glaciers in the basin heads and intense summer melting coinciding with seasonal rains.

Peña-Monné and Sampietro-Vattuone (2019) established an important glacial phase during the Younger Dryas, named the G1 phase, spanning from ca. $13 \mathrm{ky}$ to $c a .10 \mathrm{ky}$ BP. This stage coincides with the radiocarbon datings of El Rincón H1 Unit (Fig. 3a). Thus, it could be considered that the G1 phase is the most important fluvial dynamic phase at a regional level, and that it could activate the lateral widening of the upper Muñoz River course and so facilitate the upstream headward erosion of the Los Alisos 1 River tributary until it was captured.

The Los Alisos 3 River piracy is more recent and was produced by the already captured Los Alisos 2 River. It shows a rupture that is represented by a waterfall of more than $350 \mathrm{~m}$, without regularizing the river profile until present - while the capture of Los Alisos 2 was already regularized. Another stage of glacial advance, favorable for this capture process, is proposed by Peña-Monné and Sampietro-Vattuone (2019). They describe a second and less important glacial stage in the head basin named G2, between $c a$. 7 to $c a .5 \mathrm{ky}$ BP during the Neoglacial. This stage could be related with the other highlighted fluvial phase evidenced by the upper accumulations of the H1 morphosedimentary unit. Its upper chronological limit is $c a .4 .2 \mathrm{ky} \mathrm{BP}$ and contemporary with the V1 volcanic ashfall and the incision that started around these dates. Considering that the V1 ashes are not present in the Los Alisos alluvial fan, it should be younger than the ashfall. It is even possible that this alluvial fan is more recent than that and its development is linked to the strong fluvial activity produced during the Little Ice Age (LIA), when H2 and H3 units were formed (Sampietro-Vattuone and Peña-Monné, 2016). During this stage, rock glaciers were formed in the heads of the Los Alisos 2 and 3 rivers. As indicated, there are no Tafí Culture settlements over this alluvial fan and these people occupied the region between $c a .2500-2000$ and $c a .957-811 \mathrm{cal} \mathrm{BP}$. It is possible that the absence of settlements from this period in the sector is related to the 
maximum alluvial fan instability. Thus, the Los Alisos 3 capture was performed between the Neoglacial and the LIA. In any case, without more accurate evidence, this capture occurred during the Upper Holocene.

\section{Conclusions}

A capture process of two headwaters was analysed in the recently uplifted eastern side of the NE Sierra de Aconquija. The process affected the Muñoz River basin which subsequently lost $50 \%$ of its surface. One tributary of the Los Alisos River, from a lower position, acceded by headward erosion to capture the two largest headwaters of the Muñoz River. First capturing the Los Alisos 2 River and then pirating the Los Alisos 3 River and cutting a gorge more than $300 \mathrm{~m}$ deep. Meanwhile, the Los Alisos River enlarged its basin by around $73 \%$. The capture had major consequences for the alluvial fans of both rivers. Several causes can be involved to explain the capture: including the altitudinal difference $(500 \mathrm{~m})$ between these rivers; and the existence of sometimes large flows in both capturing headwaters during the Younger Dryas (Los Alisos 2 River) and the Upper Holocene (Los Alisos 3 River). There is no evidence of the influence of neotectonics on the activation of these processes, despite the existence of Holocene deformations records in the area (Las Carreras Fault 2). The captures led to the reconfiguration of the piedmont after $c a .4200$ and even conditioned Prehispanic agricultural settlements in the area.

\section{Acknowledgements}

This work is a contribution of the "Primeros Pobladores del Valle del Ebro" research group (Government of Aragon and European Social Fund), grants PIUNT G629 of the Universidad Nacional de Tucumán, PIP 837 from CONICET and PICT2019-1119 (ANPCyT). This paper fits within the research scope of IUCA (Environmental Sciences Institute of the University of Zaragoza). We are very grateful to A. Sola and W. Báez from INENCO (CONICET-UNSA) and Dr. D. A. Sampietro from LABIFITO (UNT).

\section{References}

Bishop, P. 1995. Drainage rearrangement by river capture beheading and diversion. Progress in Physical Geography 19, 449-473. http://doi.org/10.1177/030913339501900402.

Calvache, M.L., Viseras, C. 1997. Long-term control mechanisms of stream piracy processes in southeast Spain. Earth Surface Processes and Landforms 22, 93-105. https://doi.org/10.1002/ (SICI) 1096-9837(199702)22:2<93::AID-ESP673>3.0.

Casa, A.L. 2009. 5.1.6. Sistema de fallas Aconquija (AR-02). In: Proyecto Multinacional Andino (Eds.), Atlas de deformaciones cuaternarias de los Andes, 7, Publicación Geológica Multinacional, Canadá, pp. 129-136.

Casa, A., Yamin, M., Wright, E., Costa, C., Coppolechia, M., Cegarra, M. 2011. Deformaciones cuaternarias de la República Argentina. Sistema de Información Geográfica. Instituto de Geología y Recursos Minerales. Servicio Geológico Minero Argentino, 171, v.1.0, DVD.

Costa, C., Machette, M., Dart, R., Bastías, H., Paredes, J., Perucca, L., Tello, G., Haller, K. 2000. Map and database of quaternary faults and folds in Argentina. In: U.S. Geological Survey (Eds.), Open-File Report 00-0108, Map at 1:2,000,000. Denver, pp. 449-473. 
Fauqué, L., Strecker, M.R. 1987. Rasgos de neotectónica y avalanchas de roca producidas por terremotos en la vertiente occidental de los Nevados del Aconquija, Provincia de Catamarca, Argentina. In: Sociedad Argentina de Geología (Ed.), X Congreso Geológico Argentino, Sociedad Argentina de Geología, Salta, pp. 219-222.

González, A.R., Núñez Regueiro, V.A. 1960. Preliminary report on archaeological research in Tafí del Valle N.W. Argentina. 34 Internationalen Amerikanisten Kongresses, Germany, pp. 485-496.

Gutiérrez, A.A., Mon, R. 2004. Megageomorfología del valle de Tafí-Aconquija, Tucumán. Revista de la Asociación Geológica Argentina 59 (2), 303-311.

Gutiérrez, A.A., Mon, R., Vergara, G. 2003. Neotectónica: captura y decapitación del drenaje, Tucumán, Argentina. II Congreso Argentino de Cuaternario y Geomorfología, Tucumán, 293-300.

Hongn, F., Amengual, R., García, V., Yamin, M., Casa, A. 2014. Neotectónica del valle Calchaquí, Salta. In: Asociación Geológica Argentina (Ed.), XIX Congreso Geológico Argentino, Córdoba, 6, pp. 10-11.

Kemp, R.A., Thomas, P.S., Sayago, J.M., Derbyshire, E., King, M., Wagoner, L. 2003. Micromorpology and OSL dating of the basal part of loess-paleosol sequence at La Mesada in Tucumán province, Northwest Argentina. Quaternary International 106-107, 111-117. https:// doi.org/10.1016/S1040-6182(02)00166-0.

Lavé, J. 2015. Landscape inversión by stream piracy. Nature 520, 442-443. http://doi.org/10.1016/ S1040-6182(02)00166-0.

Le Roux, J.L., Harmand, D. 1998. Contrôle morphostructural de l'histoire d'un réseau hydrographique: le site de capture de la Moselle. Geodinamica Acta 11, 149-162. http://doi. org/10.1016/S0985-3111(98)80001-6.

Maldonado, M.G., Sampietro Vattuone, M.M., Blasi, A.M., Castiñeira Latorre, C., Peña Monné, J.L., Pigoni, M.A. 2016. Estratigrafía, paleoambiente y procesos de formación de sitio en El Paso durante el Holoceno tardío (valle de Santa María- Noroeste Argentino). In: M.M. Sampietro Vattuone, J.L. Peña Monné (Eds.), Geoarqueología de los Valles Calchaquíes. Laboratorio de Geoarqueología, Universidad Nacional de Tucumán, pp. 121-144.

Maher, E., Harvey, A.M., France, D. 2007. The impact of a major Quaternary river capture on the alluvial sediments of a beheaded river system, the Rio Alias SE Spain. Geomorphology 84, 344-356. https://doi.org/10.1016/j.geomorph.2005.07.034.

Mather, A.E. 1993. Basin inversion: some consequences for drainage evolution and alluvial architecture. Sedimentology 40, 1069-1089. https://doi.org/10.1111/j.1365-3091.1993. tb01380.x.

Mather, A.E. 2000. Impact of headwater river capture on alluvial system development: an example from the Plio-Pleistocene of the Sorbas Basin, SE Spain. Journal of the Geological Society London 157, 957-966. https://doi.org/10.1144/jgs.157.5.957.

Miskesell, L.R., Weissmann, G.S., Karachewski, J.A. 2010. Stream capture and piracY recorded by provenance in fluvial fan strata. Geomorhology 115, 267-277. https://doi.org/10.1016/j. geomorph.2009.04.025.

Peña Monné, J.L., Sampietro Vattuone, M.M. 2016. La secuencia paleoambiental holocena de la vertiente oriental de Loma Pelada (valle de Tafí, Noroeste Argentino): cambios climáticos y acción humana. In: M.M. Sampietro Vattuone, J.L. Peña Monné (Eds.), Geoarqueología de los Valles Calchaquíes. Laboratorio de Geoarqueología, Universidad Nacional de Tucumán, pp. 23-63.

Peña Monné, J.L., Sampietro Vattuone, M.M. 2018. Paleoambientes holocenos del valle de Tafí (Noroeste Argentino) a partir de registros morfosedimentarios y geoarqueológicos. Boletín Geológico y Minero 129 (4), 671-691. https://doi.org/10.21701/bolgeomin.129.4.005 
Peña-Monné,J.L., Sampietro-Vattuone, M.M., 2019. Geomorphological response to the LateglacialHolocene palaeoenvironmental changes in the NE piedmont of the Sierra de Aconquija (Tafí Valley, NW Argentina). Palaeogeography, Palaeoclimatology, Palaeoecology 523 (1), 7888. https://doi.org/10.1016/j.palaeo.2019.03.030.

Perucca, L.P., Espejo, K., Esper Angilieri, M.Y., Rothis, M., Tejada, F., Vargas, M. 2018. Neotectonic controls and stream piracy on the evolution of a river catchment: a case study in the Agua de la Peña River basin, Western Pampean Ranges, Argentina. Journal of Iberian Geology 44 (2), 207-224. https://doi.org/10.1007/s41513-018-0052-8.

Roldán, J., Maldonado, M.G., Urquiza, S., Vattuone, M.A., Sampietro-Vattuone, M.M. 2016. Suelos antrópicos vs. naturales: La Costa 2 (Valle de Tafí-Tucumán). Arqueología 22 (1), 127-148.

Sampietro Vattuone, M.M., 2010. Espacio, ambiente y los inicios de la agricultura indígena en el Noroeste Argentino: un enfoque geoarqueológico. JAS, Madrid.

Sampietro Vattuone, M.M., Peña-Monné, J.L., 2016. Geomorphological dynamic changes during the Holocene through ephemeral stream analyses from Northwest Argentina. Catena 247, 663-677. http://doi.org/10.1016/j.catena.2016.08.0529.

Sampietro Vattuone, M.M., Peña-Monné, J.L., 2019. Geomorphology of Tafí valley (Tucumán Province, Northwest Argentina). Journal of Maps 15 (2), 177-184. https://doi.org/10.1080/1 7445647.2019.1567403.

Sampietro Vattuone, M.M., Sola, A., Báez, W., Peña Monné, J.L. 2017. La correlación geoquímica de niveles cineríticos en la reconstrucción de las secuencias morfosedimentarias holocenas del valle de Tafí. In: C.M. Muruaga, P. Grosse (Eds.), Ciencias de la Tierra y Recursos Naturales del NOA. XX Congreso Geológico Argentino, San Miguel de Tucumán, pp. 67-72.

Sampietro-Vattuone, M.M., Peña-Monné, J.L., Roldán, J., Maldonado, M.G., Lefebvre, M.G., Vattuone, M.A. 2018. Human-driven geomorphological processes and soil degradation in Northwest Argentina: a geoarchaeological view. Land Degradation and Development 29 (11), 1-14. http://doi.org/10.1002/ldr.3128.

Sampietro-Vattuone, M.M., Báez, W.A., Peña-Monné, J.L., Sola, A. 2019. Tephrochronology and characterization of the cineritic layers interbedded in detritic Holocene deposits (Tafí and Santa María valleys, NW Argentina). Quaternary Research in press.

Schellenberger, A., Heller, F., Veit, H. 2003. Magnetostratigraphy and magnetic susceptibility of the Las Carreras loess-paleosol sequence in Valle de Taf1', Tucumán, NW-Argentina. Quaternary International 106-107, 159-167. https://doi.org/10.1016/S1040-6182(02)001702.

Sobel, E.R., Strecker, M.R. 2003. Uplift, exhumation and precipitation: tectonic and climatic control of Late Cenozoic landscape evolution in the northern Sierras Pampeanas, Argentina. Basin Research 15, 431-451. http://doi.org/10.1046/j.1365-2117.2003.00214.x.

Stamm, J.F., Hendricks, R.R., Sawyer, J.F., Mahan, S.A., Zaprowski, B.J., Geibel, N.M., Azzolini, D.C. 2013. Late Quaternary stream piracy and strath terrace formation along the Belle Fourche and lower Cheyenne Rivers, South Dakota and Wyoming. Geomorphology 197, 1020. http://doi.org/10.1016/j.geomorph.2013.03.028.

Stokes, M., Mather, A.E. 2003. Tectonic origin and evolution of a transverse drainage: the Rio Almanzora, Betic Cordillera, southeast Spain. Geomorphology 50, 59-81. https://doi. org/10.1016/S0169-555X(02)00208-8.

Stokes, M., Mather, A.E., Harvey, A.M. 2002. Quantification of river capture induced base level change and landscape development, Sorbas Basin, SE Spain. In: S.J. Jones, L.E. Frostick (Eds.), Sediment flux to basins: causes, controls and consequences. Geological Society Special Publication, London, pp. 23-54. 
Strecker, M.R. 1987. Late Cenozoic landscape development, the Santa Maria valley, northwestern Argentina. Unpublished Ph.D. Thesis, Cornell University (inédita), Ithaca, Nueva York.

Strecker, M.R., Cerveny, P., Bloom, A., Malizzia, D. 1989. Late Cenozoic tectonism and landscape development in the foreland of the Andes: Northern Sierras Pampeanas $\left(26^{\circ}-28^{\circ} \mathrm{S}\right)$, Argentina. Tectonics 8 (3), 517-534. https://doi.org/10.1029/TC008i003p00517.

Zaprowski, B.J., Evenson, E.B., Pazzaglia, F.J., Epstein, J.B. 2001. Knickzone propagation in the Black Hills and northern High Plains: A new perspective on the Late Cenozoic exhumation of the Laramide Rocky Mountains. Geology 29, 547-550. https://doi.org/10.1130/00917613(2001)029<0547:KPITBH>2.0.

Zaprowski, B.J., Evenson, E.B., Epstein, J.B. 2002. Stream piracy in the Black Hills: a geomorphology lab exercise. Journal of Geoscience Education 50 (4), 380-388. 
